\title{
Tear biochemistry: a review
}

\section{WDH Gillan*}

\author{
Department of Optometry, University of Johannesburg, PO Box 524, Auckland Park, 2006 South \\ Africa
}

$<$ wgillan@uj.ac.za>

Received 1 February 2010; revised version accepted 9 June 2010

\section{Introduction}

The tear layer has been subdivided into three separate layers: the outer oily layer, the central aqueous/ watery phase and the inner mucous layer, each being produced by different glandular or cellular systems. Several functions have been attributed to the tear layer: to form a smooth optical surface on the cornea, to lubricate the cornea and conjunctiva, to provide anti-bacterial activity, to keep the cornea moist, to serve as a conduit for the entry of polymorphonuclear leucocytes into the cornea and to remove toxic substances from the ocular surface ${ }^{1,2}$. The oily layer of the tears is produced primarily by the meibomian glands with the glands of Moll playing a role ${ }^{1}$. The meibomian glands (also known as the tarsal glands) are long sebaceous glands that are found in both the upper and lower lids. These glands are situated in the tarsal plates and number approximately 25 in the upper lid and 20 in the lower lid. The openings of the glands can be seen on the lid margin ${ }^{3}$. The glands of Moll can be considered as under- developed sweat glands that run parallel to the bulbs of the cilia ${ }^{3}$. The lacrimal gland and the accessory glands of Krause and Wolfring produce the middle aqueous layer of the tears. The lacrimal gland has two separate portions: a large orbital portion and a smaller palpebral portion. The lacrimal gland accounts for approximately 95\% of the aqueous phase of the tears ${ }^{2}$. New evidence suggests, however, that the aqueous layer only makes up $60 \%$ of the thickness of the tear layer ${ }^{4}$. The orbital portion of the gland can be found in a fossa in the lateral roof of the orbit while the palpebral portion is placed just above the lateral section of the upper fornix $^{3}$. The glands of Krause have the same structure as the lacrimal gland and are placed in the subconjuncti- val tissue of the upper fornix. The glands of Wolfring are larger than the glands of Krause and are situated in the upper lid along the upper border of the tarsus ${ }^{3}$. The mucous layer of the tears is produced by the goblet cells of the conjunctiva. Goblet cells can be found in all areas of the conjunctiva and are large oval or round cells ${ }^{3}$.

The tears contain numerous components. Broadly speaking proteins (mucins, enzymes, glycoproteins, immunoglobulins etc), lipids, electrolytes, water and organic solutes are to be found in the tear layer ${ }^{1-4}$. The aqueous layer of the tear film contains predominantly proteins, water and electrolytes ${ }^{5}$ while the outermost oily layer contains several classes of lipids (for example: wax esters, triglycerides, free fatty acids and polar lipids) and neutral diesters ${ }^{6-7}$ and the inner-most mucin (glycoproteins) layer contains mucin types that are considered to be secreted or membrane-associat$\mathrm{ed}^{8-10}$.

The lacrimal gland receives innervation primarily from the parasympathetic nervous system and is regulated mainly by the cholinergic fibres of this system, however, adrenergic sympathetic stimulation, peptide agents and humoral factors all play a role in modulating the processes of this gland ${ }^{5-7}$. The regulation of the lacrimal gland has proved to be an exceptionally complex process ${ }^{2}$. Afferent sensory nerves originating in the cornea and conjunctiva may be stimulated by mechanical, thermal and/or chemical stimuli which in turn result in stimulation of the lacrimal gland 5 . Light, via the optic nerve, can also stimulate the lacrimal gland ${ }^{5}$. Epidermal growth factor (EGF), a member of the growth factor family, has been shown to stimulate and modify the neural regulation of the lacrimal gland ${ }^{5,11}$. The neurotransmitters released by the para- 
sympathetic and sympathetic nerves have been shown to be the most powerful stimuli of lacrimal gland function ${ }^{5}$. The detailed biochemical pathways involved are beyond the scope of this review. The interested reader is referred to a number of detailed reviews for an in-depth discussion of these pathways ${ }^{5,11-13}$.

Meibomian gland regulation seems to be dual natured ${ }^{14}$ (at the least). Neural influences have been shown by several researchers 15,16 . The cholinergic system has been suggested as being involved in the regulation of human meibomian glands ${ }^{15}$. This view is supported by others ${ }^{16-18}$ who have shown results (investigating rat meibomian glands) strongly suggesting that the parasympathetic nervous system modulates the functioning of the meibomian glands. A further regulating influence on the meibomian gland is androgens ${ }^{19-21}$. An androgen is: "any number of hormones, such as testosterone, that influence the development of the male reproductive system" 22 . Androgens appear to play a role in stimulating the synthesis and secretion of lipids from the meibomian glands, however, the exact mechanism by which this process is regulated is not clear at present ${ }^{20}$. Sullivan et $a l^{20}$ have shown that androgen deficiencies may result in altered lipid patterns in human meibomian gland secretions.

The regulation of conjunctival goblet cells is also a complicated process and only a superficial discussion will be presented in this review (the interested reader can consult excellent reviews on this specific subject by referring to Dartt $\left.{ }^{23}, 24\right)$. The conjunctiva has two layers, the stratified epithelial layer and the underlying stroma ${ }^{3}$. The epithelial layer has further been subdivided into five different cell types ${ }^{25}$. However, in this context epithelial cells are classified as goblet cells or stratified squamous cells. It has been shown that $\mathrm{Ca} 2+$ has an influence on cholinergic-induced goblet cell secretion ${ }^{26}$. Stimulation of the goblet cell can also be influenced by the enzyme protein kinase $\mathrm{C}$ (PKC) of which the conjunctival goblet cells contain seven different isoforms ${ }^{26}$ ("catalytically and structurally similar but genetically distinct enzymes from the same organism" 24$)$. Goblet cells are surrounded by both parasympathetic and sympathetic nerve fibres ${ }^{27}$ thus some autonomic influence might be inferred. Evidence has been provided to suggest that parasympathetic nerves, acting via acetylcholine and vasoactive intestinal polypeptide 28 (VIP), can stimulate goblet cell secretions ${ }^{23}$. Acetylcholine, however, does not stimulate stratified cells. PKC stimulates goblet cells but inhibits stratified cells ${ }^{23}$. Ca2+, on the other hand, stimulates both goblet cells and stratified cells ${ }^{23}$. The suggestion is that neural stimulation of conjuntival secretion depends on which nerves and which neurotransmitters are released ${ }^{23}, 24$. EGF also appears to play some role in goblet cell regulation ${ }^{23}$.

The division of tear components into proteins, lipids and mucins is largely arbitrary yet also loosely related to the predominant components found in the three different layers of the tears. There is, admittedly, overlap. For example: all enzymes are proteins, the mucins are essentially glycoproteins, immunoglobulins are proteins and so on.

\section{Proteins}

Approximately 500 different proteins have been identified in the tears of the closed eye (de Souza et $a l^{29}$ cited in Laurie et $a l^{30}$ ). Early electrophoretic investigations into proteins present in the tears revealed at least 60 different proteins ${ }^{31}$. Of the 60 proteins identified at least 20 were shown to be secreted by the lacrimal gland ${ }^{31}$. Furthermore the proteins present in tears were found to be products of a local synthesis process as opposed to originating from blood circulation $^{32}$.

The three principle proteins found in tears are lysozyme, lactoferrin and tear-specific prealbumin (lipocalin) ${ }^{2}, 32,33$. Lysozyme is an enzyme (a protein) that is capable of destroying cell walls by breaking bonds (known as glycosidic bonds) between carbohydrate units in the peptidoglycans of the cell walls of bacteria ${ }^{34,35}$. Tears, at least partially, have bacteriolytic activity due to the presence of lysozyme ${ }^{36}$. Lactoferrin too has antimicrobial activity as well as a possible role in ocular surface protection from free radicals ${ }^{2}$. The specific activity of tear-specific prealbumin (lipocalin) in tears is open to speculation at present ${ }^{2}$. However, it has been suggested that lipocalin has several important functions in the tear layer. Lipocalins may offer protection to the cornea by acting as clearance factors for harmful lipophilic substances ${ }^{37}$ or they might contribute to the effective spreading of lipids over the tear film ${ }^{38}$.

Using electrophoresis combined with immunologic identification, Coyle et $a^{39}$ showed the presence of 
other proteins including albumin, $\operatorname{IgA}, \mathrm{IgG}$, secretory component and transferrin. Membrane-bound antibody arrays (MA) have been used to identify many other proteins in tears ${ }^{40}$. Epidermal growth factor (EGF), monocyte chemoattractant protein, tissue inhibitor metalloproteinase (TIMP), angiogenin, chemokines, cytokines, growth-related oncogene, epithelial neutrophil-activating protein and macrophage inflammatory protein have all been detected using $\mathrm{MA}^{40,41}$. Growth factors, including EGF, are a family of factors that are able to regulate ocular surface wound healing, and corneal and conjunctival epithelial cell proliferation, differentiation, growth and development. EGF is also able to stimulate and modify lacrimal gland secretion. The EGF family are important regulators not only of the lacrimal gland but of the ocular surface as well ${ }^{5}$. Matrix metalloproteinases (MMP) are a family of zinc-dependant endopeptidases that are capable of degenerating all types of extracellular proteins ${ }^{4}$. They are also known to process bioactive molecules and to play a role in cell proliferation, migration, differentiation, angiogenesis and apoptosis ${ }^{4}$. The effects of MMP's can be counteracted by naturally occurring MMP inhibitors (TIMP) ${ }^{4}$.

Immunoglobulins (antibodies) are glycoproteins that bind antigens (invading organisms) with a high specificity and affinity. There are five distinct classes of immunoglobulin ( $\operatorname{Ig}$ A, $\operatorname{IgG}, \operatorname{IgM}, \operatorname{IgD}$ and $\operatorname{IgE}$ ). The immunoglobulins play an important part in the immune system ${ }^{42}$. Cytokines are protein or glycoprotein molecules that are secreted by cells in response to specific stimuli42. "Cytokines are multifunctional short-acting, short-range mediators of cellular activity that are released by $\mathrm{T}$ cells and other immune and non-immune cells"4. Cytokines play a critical role in inter-cellular communication and may induce growth, differentiation, chemotaxis and/or cytotoxicity ${ }^{42}$. Chemokines are a small group of cytokines with the express function of chemoattraction of lymphocytes, monocytes and neutrophils, all of which play a role in the immune response ${ }^{42}$. Angiotensin II (an octapeptide), a powerful vasopressor agent, formed by the action of angiotensin-converting enzyme, have both been isolated in human tears ${ }^{43}$. The suggestion has been made that the presence of these agents implies some physiological function for angiotensin in the eye ${ }^{43}$ (the exact function needs to be elucidated). Insulin and insulin-like growth factor have been iso- lated in the tears of human eyes ${ }^{44}$. Diabetes is known to be related to dry eye and altered ocular wound healing and the implication is that insulin may play a relevant role in ocular surface physiology ${ }^{44}$. Lacritin is another protein found in human tears. Its acts as a prosecretory mitogen (growth factor) that may play an important role in lacrimal secretion, and renewal of lacrimal and ocular surface epithelial structure ${ }^{45}$.

Tear proteins are known to play a role in the antimicrobial and anti-inflammatory defences of the eye. They probably are also important in normal epithelial growth, protein/fluid/electrolyte secretion and many other aspects of normal ocular physiology, including (but probably not restricted to): angiogenesis, biosynthesis, calcium and carbohydrate metabolism, cell adhesion and motility, cell growth, anti-apoptosis, immunology and lipid/cholesterol metabolism ${ }^{30}$.

\section{Lipids}

The exact roles that lipids play in the tear film are not completely agreed upon. However, the principal roles that lipids play are suggested as being the following 46,47 : to act as a wettability barrier and contain the tears within the palbebral aperture, prevent maceration of the skin of the lids, to form a seal over exposed portions of the eye during sleep, prevent contamination of the tears by sebaceous lipids, reduce tear evaporation, impart stability to the tear layer, provide a smooth optical surface to the eye, provide some anti-microbial activity and to lower free energy of the tear film surface. The tear lipid layer is almost exclusively produced by the meibomian glands of the lids which are tubulo-acinar, holocrine in nature ${ }^{47}$. The major constituents of meibomian lipids include: wax esters, cholesterol and cholesterol esters (non-polar lipids) which make up $60-70 \%$ of the lipids found in the tears. Polar lipids are also present and are mainly phospholipids and glycolipids ${ }^{46,47}$. Diesters, hydrocarbons, mono-, di- and triglycerides, free fatty acids and alcohols are also to be detected 46,47 . When comparing meibomian and internal tissue lipids a striking difference between them is the presence of branch chains in meibomian lipids ${ }^{46}$. Carbon numbers (the number of carbon atoms in the fatty acid chain) are predominantly even in number for normal and isochains while anteiso-chains always have odd carbon numbers. Meibomian lipids also have a much wider 
range of chain lengths when compared with tissue lipids ${ }^{46}$. The biosynthesis processes involved in the synthesis of the lipids are probably the cause of such differences ${ }^{46}$. Mass spectrometry (MS) has proven to be an important tool in analysing tear lipids. Oleamide, a fatty acid, phosphocholine (a sphingomyelin), myristamide, palmitamide, stearamide, erucamide (all fatty acid amides) and free fatty acids (myristic, palmitic, stearic and oleic) have all been identified in tear lipids ${ }^{48,} 49$ making use of MS. Butovich ${ }^{50}$, however, found oleamide to make up an extremely minor component of meibum (below $0.5 \%$ of dry meibum weight) and suggested that improper laboratory and collection techniques resulted in previous reports of significant amounts of oleamide being present in tear lipids. Other components of tear lipids detected by MS include: squalene, steroids and steryl esters, wax esters and di- and triacyl glycerols ${ }^{50}$. An apparently new group of lipid compounds in tear lipids have recently been identified using MS. A diacylglycerol-based anionogenic lipid has been detected by the MS technique ${ }^{51}$. Meibomian secretions have also been shown to contain proteinaceous material ${ }^{52}$. The transport of fatty acylglycerols in the circulation involves an entity known as a chylomicron ${ }^{34}$. The transfer of phospholipids from the chylomicron and very low density lipoproteins (VLDL) to high density lipoproteins (HDL) requires the presence of phospholipid transfer protein (PLTP $)^{53}$. PLTP has been isolated in human tears and is thought to play a role in the transfer of meibomian lipids to the surface of the tear layer ${ }^{54}$. Other possible roles that PLTP may play are to scavenge hydrophobic material from the cornea or to scavenge lipids by binding and transporting them into and through the lacrimal drainage system 54 .

The statement "The great diversity of lipids found in the meibomian glands and aqueous tears, which are estimated to be present as thousands of individual species, makes it impossible to evaluate, identify and quantify them in one study..."50 implies that there is still much to be discovered relating to the lipids present in human tears and their functions.

\section{Mucins}

Mucin found on the ocular surface is typically described as: "being associated with two sub-layers: an innermost tightly bound glycocalyx layer that is se- creted by, and in intimate contact with, the microplicae of the conjunctival and corneal epithelia and an overlying thicker and looser mucous blanket believed to be produced by the conjunctival goblet cells" 8 . The glycocalyx is an extrinsic, carbohydrate-rich surface coat that is found along the apical surfaces of the epithelial cells ${ }^{55}$. The functions of mucin on the eye are considered to be: lubricate and protect the ocular surface, anchor the aqueous tear layer to the ocular surface, protect the epithelium from sheer force damage, drying and bacterial invasion and to provide a hydrophobic scaffold to hold other anti-microbial proteins to the eye ${ }^{56,57}$. Mucins can be defined as: "glycoproteins, hydrophilic in nature, that have at least $50-80 \%$ of their mass as carbohydrate, O-linked to serine and threonine residues present within tandem repeats of amino acids in their protein backbone" (Gendler and Spicer ${ }^{58}$ cited in Spurr-Michaud et al ${ }^{9}$ ). The number of genes found, coding for mucin, have increased over the years as the technology to detect them has improved (2000: 9 genes $^{56}$, 2001: 14 genes $^{57}$, 2004: 17 genes $^{10}, 2007: 20$ genes $\left.^{9}\right)$. The genes are named and numbered chronologically in order of their discovery and are indicated as MUC1, MUC2 etc $^{57}$. A common characteristic, the presence of a tandemly repeated nucleotide (TR) sequence located in the central part of the gene, is found in all mucin coding genes ${ }^{57}$. Each gene can result in the production of a specific mucin appropriately named MUC1, MUC2 etc. Depending on the conformation of the mucin molecule, mucins have been classified as secreted mucins (includes gelforming and soluble mucins) and membrane-spanning mucins ${ }^{57,58}$. Secreted mucins are responsible for the rheological properties of mucous and are secreted by the goblet cells while membrane-spanning mucins might interact with intercellular proteins (this does need to be investigated further) ${ }^{57}$. The genes coding for the secreted mucins are all found clustered in the same locus on chromosome $11 \mathrm{p} 15.5^{57}, 58$. The proteins transcribed from the relevant mucin genes are amongst the largest glycoproteins known with an average molecular weight of approximately $40 \mathrm{MDa}^{57}$. MUC's 1, 3A, 3B, 4, 12, 13, 15, 16, 17 and 20 have been classified as membrane-spanning mucins while MUC's 2, 5AC, 5B, 6, 7, and 19 are classified as secreted mucins 9 . Mucins MUC 1, 2, 4, 5AC and 16 have been found in the tear film ${ }^{9}$. Mucins MUC 459 and $16^{59,60}$ are thought to be particularly important 
in maintaining a healthy ocular surface. Recent data suggest three particular membrane-spanning mucins, MUC's 1, 4, and 16, play an important role in dry eye $^{61}$. Also reported in a recent "article in press" 62 is data showing that tumor necrosis factor- $\alpha$ (TNF$\alpha)$ and interferon- $\gamma$ (INF- $\gamma$ ) have dramatic effects on MUC's 1 and 16, two of the major mucins found on the corneal surface. Both TNF- $\alpha$ and INF- $\gamma$, inflammatory mediators, are present in dry eye patients and may play a role in ocular surface mucin function.

\section{Closure}

One might wonder why it is important for optometry to be aware of the biochemistry of the tear film. Ageing has been shown to be related to alterations in polar as well as neutral lipid profiles of the tear film ${ }^{63}$ and as alluded to above, lipids (and age) play a role in the quality of the tear film. Biochemical changes have been shown in the tears and corneas of keratoconic patients, when compared with non-keratoconic patients ${ }^{64}$. Dry eye has been shown to up-regulate at least six different tear proteins while down-regulating at least four ${ }^{65}$. Contact lens wear can also result in changes to tear biochemistry ${ }^{66}$. Changes in meibomian gland lipid secretions have been suggested as being causative in blepharitis ${ }^{67}$. There are numerous instances where an understanding of biochemistry (even a superficial understanding) would enhance optometry's ability to make improved decisions regarding many relevant clinical entities.

\section{Acknowledgments}

My appreciation goes to Ms L Joubert and Dr G Koorsen for helpful comments relating to the content of this review.

\section{References}

1. Fatt I, Weissman BA. Physiology of the eye: an introduction to the vegetative functions. 2nd ed. Stoneham: Butterworth-Heinneman, 1992.

2. Berman ER. Biochemistry of the eye. New York: Plenum Press, 1991.

3. Warwick R. Eugene Wolff's anatomy of the eye and orbit. 7th ed. London: HK Lewis and CO. 1976.

4. Forrester JU, McMenamin PG, Roberts F. The eye: basic sciences in practice, 3rd ed. London: Saunders-Elsevier, 2008.
5. Dartt DA. Interaction of EGF family growth factors and neurotransmitters in regulating lacrimal gland secretion. Exp Eye Res 200478 337-345.

6. Tiffany JM. Physiological functions of the meibomian glands. Prog Ret Eye Res 199514 47-74.

7. McCulley JP, Shine WE. The lipid layer of tears, dependent on meibomian gland function. Exp Eye Res 200478 361365 .

8. Ramamoorthy P, Nichols JJ. Mucins in contact lens wear and dry eye. Optom Vis Sci 200885 631-642.

9. Spurr-Michaud S, Argüeso P, Gipson IK. Assay of mucins in human tear fluid. Exp Eye Res 200784 939-950.

10. Gipson IK. Distribution of mucins at the ocular surface. Exp Eye Res 200478 379-388.

11. Dartt DA. Regulation of lacrimal gland secretion by neurotransmitters and the EGF family of growth factors. Exp Eye Res 200173 741-752.

12. Wu K, Galina VJ, da Costa SR, Sou E, Schechter JE, HammAlvarez SF. Molecular mechanisms of lacrimal acinar secretory vesicle exocytosis. Exp Eye Res 200683 84-96.

13. Dartt DA. Neural regulation of lacrimal gland secretory processes: relevance in dry eye diseases. Prog Ret Eye Res 200928 155-177.

14. Bron AJ, Tiffany JM. The meibomian glands and tear film lipids: structure, function and control. In: Sullivan DA, Dartt DA, Meneray MA eds Lacrimal gland, tear film and dry-eye syndromes. New York: Plenum Press, 1998.

15. Perra MT, Serra A, Sirigu P, Turno F. Histochemical demonstration of acetylcholinesterase activity in human meibomian glands. Eur J Histochem 199640 39-44.

16. LeDoux MS, Zhou Q, Murphy RB, Greene ML, Ryan P. Parasympathetic innervation of the meibomian glands in rats. Inv Ophthal Vis Sci 200142 2434-2441.

17. Chung CW, Tigges M, Stone RA. Peptidergic innervation of the primate meibomian gland. Inv Ophthal Vis Sci 1996 37 238-245.

18. Seifert P, Spitznas M. Vasoactive intestinal polypeptide (VIP) innervation of the human eyelid glands. Exp Eye Res 199968 685-692.

19. Perra MT, Lantini MS, Serra A, Cossu M, De Martini G, Sirigu P. Human meibomian glands: a histochemical study for androgen metabolic enzymes. Inv Ophthal Vis Sci 1990 31 771-775.

20. Schirra F, Richards SM, Liu M, Suzuki T, Yamagami H, Sullivan DA. Androgen regulation of lipogenic pathways in the mouse meibomian gland. Exp Eye Res 200683 291-296.

21. Sullivan DA, Sullivan BD, Evans JE, Schirra F, Yamagami H, Liu M, Richards SM, Suzuki T, Schaumberg DA, Sullivan RM, Dana MR. Androgen deficiency, meibomian gland dysfunction and evaporative dry eye. Ann New York Acad Sci 2006996 211-222.

22. Allen R. ed. The Penguin dictionary. London: Penguin books, 2004.

23. Dartt DA. Regulation of mucin and fluid secretion by conjunctival epithelial cells. Prog Ret Eye Res 200221 555576.

24. Dartt DA. Control of mucin production by ocular surface epithelial cells. Exp Eye Res 200478 173-185. 
25. Pepperl JE, Ghuman T, Gill KS, Zieske JD, Trocome SD. Conjunctiva. In: Tazman W, Jaeger E. eds: Duane's Foundations of Clinical Ophthalmology. Vol 1. Philadelphia: Lippincott Williams and Williams, 1996.

26. Dartt DA, Rios JR, Kanno H, Rawe IM, Zieske JD, Ralda N, Hodges RR, Zoukhri D. Regulation of conjunctival goblet cell secretion by $\mathrm{Ca} 2+$ and protein kinase C. Exp Eye Res 200071 619-628.

27. Dartt DA, McCarthy DM, Mercer DM, Kessler TL, Chung $\mathrm{EH}$, Zieske JD. Localization of nerves adjacent to goblet cells in rat conjunctiva. Curr Eye Res 199514 993-1000.

28. Seifert P, Spitznas M. Vasoactive intestinal polypeptide (VIP) innervation of the human eyelid glands. Exp Eye Res 199968 685-692.

29. de Souza GA, Godoy LM, Mann M. Identification of 491 proteins in the tear fluid proteome reveals a large number of proteases and protease inhibitors. Genome Biol 20067 R72.

30. Laurie GW, Olsakovsky LA, Conway BP, McKown RL, Kitagawa K, Nichols JJ. Dry eye and designer ophthalmics. Optom Vis Sci 200885 643-652.

31. Gachon AM, Verrelle P, Betail G, Dastugue B. Immunological and electrophoretic studies of human tear proteins. Exp Eye Res 197929 539-553.

32. Janssen PT, Van Bijsterveld P. Origin and biosynthesis of human tear proteins. Inv Ophthal Vis Sci 198324 623630.

33. Green-Church K, Nichols KK, Pitsch RL, Ham BM, Perez $\mathrm{R}$, Nichols JJ. Comparison of proteomic methods for tear profiling. Inv Ophthal Vis Sci 200647 e-abstract 3535.

34. Voet DJ, Voet JG, Pratt CW. Principles of biochemistry, 3rd ed. New Jersey: John Wiley and Sons, 2008.

35. Whikehart DR. Biochemistry of the eye, 2nd ed. Philadelphia: Butterworth-Heinemann, 2003.

36. Phillips AJ, Stone J. Contact lenses, 3rd ed. London: Butterworths, 1989.

37. Flower DR. The lipocalin protein family: structure and function. Biochem J 1996318 1-14.

38. Holzfeind P, Merschak P, Dieplinger H, Redl B. The human lacrimal gland synthesizes apolipoprotein D mRNA in addition to tear prealbumin mRNA, both species encoding members of the lipocalin family. Exp Eye Res 199561 495-500.

39. Coyle PK, Sibony PA, Johnson C. Electrophoresis combined with immunologic identification of human tear proteins. Inv Ophthal Vis Sci 198930 1872-1882.

40. Sack RA, Conradi L, Krumholz D, Beaton A, Sathe S, Morris C. Membrane array characterization of 80 chemokines, cytokines and growth factors in open- and closed-eye tears: angiogenin and other defense system constituents. Inv Ophthal Vis Sci 200546 1228-1238.

41. Shimin L, Sack R, Vijmasi T, Sathe S, Beaton A, Quigley D, Gallup M, McNamara NA. Antibody protein array analysis of the tear film cytokines. Optom Vis Sci $2008 \mathbf{8 5}$ 653-660.

42. Lydyard P, Whelan A, Fanger M. Immunology, 2nded. Abingdon: Taylor and Francis, 2007.
43. Vita JB, Anderson JA, Hulem CD, Leopold IH. Angiotensin-converting enzyme activity in ocular fluids. Inv Ophthal Vis Sci 198120 255-257.

44. Rocha EM, Cunha DA, Carneiro EM, Boschero AC, Saad MJA, Velloso LA. Identification of insulin in the tear film and insulin receptor and IGF-I receptor on the human ocular surface. Inv Ophthal Vis Sci 200243 963-967.

45. Ma P, Wang N, McKown RL, Raab RW, Laurie GW. Focus on molecules: Lacritin. Exp Eye Res $2008 \mathbf{8 6}$ 457-458.

46. Tiffany JM. Physiological functions of the meibomian glands. Prog Ret Eye Res 199514 47-74.

47. Bron AJ, Tiffany JM. Gouveia SM, Yokoi N, Voon LW. Functional aspects of the tear film lipid layer. Exp Eye Res $200478347-360$.

48. Green-Church KB, Zeigler C, Nichols JJ, Nichols KK. Identification and analysis of polar and non-polar lipids from meibomian gland secretions using electrospray ionization mass spectrometry. Inv Ophthal Vis Sci 200546 Eabstract 4421.

49. Nichols KK, Ham BM, Nichols JJ, Zeigler C, GreenChurch KB. Identification of fatty acids and fatty acid amides in human meibomian gland secretions. Inv Ophthal Vis Sci 200748 34-39.

50. Butovich IA. On the lipid composition of human meibum and tears: comparative analysis of nonpolar lipids. Inv Ophthal Vis Sci 200849 3779-3789.

51. Butovich IA, Uchiyama E, McCulley JP. Lipids of human meibum: mass-spectrometric analysis and structural elucidation. J Lipid Res 200748 2220-2235.

52. Evans JE, Green KM, Sullivan RM, Schaumberg DA, Dana MR, Sullivan DA. Proteomic analysis of human meibomian gland secretions. ARVO abstract 2003 abstract 2478.

53. Setälä NL, Holopainen JM, Metso J, Wiedmer SK, Yohannes G, Kinnunen PKJ, Ehnholm C, Jauhiainen M. Interfacial and lipid transfer properties of human phospholipid protein: implications for the transfer mechanism of phospholipids. Biochem 200746 1313-1319.

54. Jauhiainen M, Setälä NL, Ehnholm C, Metso J, Tervo TMT, Eriksson O, Holopainen JM. Phospholipid transfer protein is present in human tear fluid. Biochem 200544 8111-8116.

55. Gipson IK, Yankauckas M, Spurr-Michaud SJ, Tisdale AS, Rinehart W. Characteristics of a glycoprotein in the ocular surface glycocalyx. Inv Ophthal Vis Sci 199233 218-227.

56. McKenzie RW, Jumblatt JE, Jumblatt MM. Quantification of MUC2 and MUC5AC transcrips in human conjunctiva. Inv Ophthal Vis Sci 200041 703-708.

57. Argüeso P, Gipson IK. Epithelial mucins of the ocular surface: structure, biosynthesis and function. Exp Eye Res 200173 281-289.

58. Gendler SJ, Spicer AP. Epithelial mucin genes. Annu Rev Physiol 199557 607-634.

59. Hori Y, Spurr-Michaud S, Russo CL, Argüeso P, Gipson IK. Differential regulation of membrane-associated mucins in the human ocular surface epithelium. Inv Ophthal Vis Sci 200445 114-122. 
60. Perez BH, Gipson IK. Focus on molecules: human mucin MUC16. Exp Eye Res 200887 400-401.

61. Argüeso P, Spurr-Michaud S, Russo CL, Tisdale A, Gipson IK. MUC16 mucin is expressed by the human ocular surface epithelia and carries the H185 carbohydrate epitope. Inv Ophthal Vis Sci 200344 2487-2495.

62. Albertsmeyer A-C, Kakkassery V, Spurr-Michaud S, Beeks O, Gipson IK. Effect of pro-inflammatory mediators on membrane-associated mucins expressed by human ocular surface epithelial cells. Article in press. Exp Eye Res 2010 $1-8$.

63. Sullivan BD, Evans JE, Dana R, Sullivan DA. Influence of aging on the polar and neutral lipid profiles in human meibomian gland secretions. Arch Ophthal 2006124 12861292.

64. Nielsen K, Vorum H, Fagerholm P, Birkenkamp-Demtröder K, Honoré B, Ehlers N, Orntoft TF. Proteome profiling of corneal epithelium and identification of marker proteins for keratoconus, a pilot study. Exp Eye Res 200682 201-209.

65. Zhou L, Beuerman RW, Chan CM, Zhao SZ, Li XR, Yang $\mathrm{H}$, Tong L, Liu S, Stern ME, Tan D. Identification of tear fluid biomarkers in dry eye syndrome using iTRAQ quantitative proteomics. J Prot Res 2008 4889-4905.

66. Thakur A, Willcox MDP. Cytokine and lipid inflammatory mediator profile of human tears during contact lens associated inflammatory diseases. Exp Eye Res 1998 67 9-19.

67. Shine WE, McCulley JP. Role of wax ester fatty alcohols in chronic blepharitis. Inv Ophthal Vis Sci 199334 35153521 . 